\title{
Cross-cultural adaptation and content validation into Portuguese of the Subjective Global Nutritional Assessment for pediatric patients hospitalized with cancer
}

\author{
Adaptação transcultural e validação do conteúdo \\ em português da Pediatric Subjective Global \\ Nutritional Assessment em pacientes \\ pediátricos hospitalizados com câncer
}

Danúbia da Cunha Antunes SARAIVA ${ }^{1}$

Wanélia Vieira AFONSO ${ }^{1}$

Nivaldo Barroso de $\mathrm{PINHO}^{2}$

Wilza Arantes Ferreira PERES 3

Patricia de Carvalho PADILHA ${ }^{3}$

A B S T R A C T

\section{Objective}

Cross-cultural adaptation and content validation of the Brazilian Portuguese version of the Subjective Global Nutritional Assessment questionnaire (originally in English) for use in hospitalized children and adolescents being treated in a reference institute of oncology.

\footnotetext{
1 Instituto Nacional de Câncer José Alencar Gomes da Silva, Hospital do Câncer I, Serviço de Nutrição e Dietética. Rio de Janeiro, RJ, Brasil.

2 Instituto Nacional de Câncer José Alencar Gomes da Silva, Hospital do Câncer I, Divisão de Apoio Técnico. Rio de Janeiro, RJ, Brasil.

${ }^{3}$ Universidade Federal do Rio de Janeiro, Instituto de Nutrição Josué de Castro, Departamento de Nutrição e Dietética. Av. Carlos Chagas Filho, 373, Bloco J, Sala 7, Ilha do Fundão, 21941-590, Rio de Janeiro, RJ, Brasil. Correspondência para/Correspondence to: DCA SARAIVA. E-mail: <dcasaraiva@gmail.com>.

Article based on the master's thesis of DCA SARAIVA, intitled: "Adaptação transcultural de um questionário de triagem nutricional em pacientes pediátricos hospitalizados com câncer”. Universidade Federal do Rio de Janeiro; 2014.
} 


\section{Methods}

The cross-cultural adaptation process consisted of the following stages: conceptual, item, semantic, and operational equivalence. The conceptual equivalence and item was carried out through discussion with members of an expert committee. Semantic equivalence was evaluated through initial translation, synthesis of translations, back translation, discussions with experts, and pretest with 32 patients. During operational equivalence, the experts discussed about the format of questions and instructions, setting, target populations, and mode of administration to later propose a final version. Content validation was performed by the expert committee.

\section{Results}

Minor modifications were made in the instrument to facilitate its use in the Brazilian socio-cultural context. Pretest results showed that the instrument is easily understood by health care professionals and the target population.

\section{Conclusion}

The cross-cultural adaptation and validation of the Subjective Global Nutritional Assessment allowed obtaining a Brazilian version equivalent to the original. The adapted instrument will be an important tool for the subjective assessment of the nutritional status of pediatric patients hospitalized with cancer.

Keywords: Cross-cultural comparison. Neoplasms. Nutrition assessment. Pediatrics.

\section{RE S U M O}

\section{Objetivo}

Realizar a adaptação transcultural e validação do conteúdo do questionário de Avaliação Nutricional Subjetiva Global Pediátrica do inglês para o português brasileiro em crianças e adolescentes hospitalizados atendidos em um instituto de referência em oncologia.

\section{Métodos}

O processo de adaptação transcultural seguiu as etapas: equivalência conceitual, de item, semântica e operacional. A equivalência conceitual e de item foi realizada por meio da discussão com o comitê de especialistas. Para apreciação da equivalência semântica foram realizadas as etapas de tradução inicial, síntese das traduções, retrotradução, discussão com os especialistas e pré-teste em 32 pacientes. Na equivalência operacional foi discutido com os especialistas o veículo e formato das questões/instruções; cenário de administração e pelo modo de aplicação para posteriormente propor uma versão final e a validação de conteúdo foi realizada por meio do comitê de especialistas.

\section{Resultados}

Foram realizadas pequenas modificações no instrumento Avaliação Nutricional Subjetiva Global Pediátrica de forma a facilitar seu uso no nosso contexto sócio-cultural. Os resultados do pré-teste mostraram que o instrumento é facilmente compreendido entre os profissionais de saúde e a população-alvo.

\section{Conclusão}

A adaptação transcultural e a validação do conteúdo da Avaliação Nutricional Subjetiva Global Pediátrica permitiram uma versão brasileira equivalente ao original. O instrumento resultante da adaptação será importante para a avaliação subjetiva do estado nutricional de pacientes pediátricos hospitalizados com câncer.

Palavras-chave: Comparação transcultural. Neoplasias. Avaliação nutricional. Pediatria.

\section{INTRODUCTION}

When compared to its prevalence in adults, cancer in children is considered rare, accounting for $2 \%$ to $3 \%$ of all malignant tumors [1]. It was estimated that in 2014 there would be 11,840 new cases of cancer in children and adolescents in Brazil [2].
Although advances in treatment have increased the overall five-year survival rate to approximately $80 \%$, pediatric cancer is still the second leading cause of death (followed accidents only) in children 5-14 years [3], reflecting a serious global public health problem. 
Maintaining an adequate nutritional status during antineoplastic treatment is a major challenge because of the treatment side effects and metabolic changes that contribute to weight loss and growth retardation in pediatric patients with cancer [4]. Malnutrition is associated with increased morbidity and mortality rates $[5,6]$.

There are many techniques available to assess the nutritional status of pediatric patients. The choice of the technique will depend on hospital resources, diagnostic, and the patient's clinical conditions [4]. However, all nutritional assessment methods that rely on weight-related measurements can be misleading in pediatric cancer patients since tumor masses can reach up to $10 \%$ of total body weight [7]. Objective and subjective data should be used to complete the nutritional assessment [4].

To prevent malnutrition, especially hospitalacquired malnutrition, nutritional risk needs to be identified at the time of admission to ensure that appropriate nutritional intervention can be initiated at an early stage. Routine nutritional screening is rarely carried out in pediatric patients due to the lack of a simple and validated method for this population [8].

The Subjective Global Nutritional Assessment (SGNA) pediatric tool was adapted and validated by Secker \& Jeejeebhoy [9] for use in a Canadian pediatric population. It is a subjective nutritional status assessment that takes into account current information on the child's body weight and height, dietary intake, frequency and duration of gastrointestinal symptoms, metabolic stress, current functional capacity, and recent changes. The use of this tool allows classifying the patients as: well nourished, moderately malnourished, and severely malnourished $[9,10]$.

Most of nutritional screening tools available, including the SGNA, have been developed in English speaking countries, and therefore they need to be translated and adapted for use in other countries. The cross-cultural adaptation should be a combination between the literal translation of words and phrases from one language into another, ensuring equivalence between the original source and the adapted version so that it adapted version can be used in the targeted culture [11].

The aim of the present study was performing the cross-cultural adaptation and content validation of the Brazilian Portuguese version of the SGNA questionnaire for use in pediatric patients hospitalized with cancer.

\section{METHODS}

This is a descriptive study of a cross-cultural adaptation process designed to maximize the attainment of conceptual and item equivalence, semanticequivalence, and operational equivalence and content validation [11-13] (Figure 1).

The Subjective Global Nutritional Assessment consists of two questionnaires, one to be completed by health care professionals and another to obtain clinical history information focusing on infant ( 0 to 2 years) and also on children and adolescent (2-18 years) nutritional information. The form that has to be filled out by health care professionals and the questionnaire for assessment of children and adolescents were subjected to cross-cultural adaptation because of the population of interest in the present study.

The health care professional form includes 15 questions or statements distributed as follows: adequacy of weight and height (7), dietary intake (3), gastrointestinal symptoms (2), functional capacity (2), and metabolic stress (1). There is also a field for the evaluation of the physical examination, which takes into account the adipose fat, muscle mass, and the presence of edema in some anatomical regions.

The questionnaire to obtain clinical history data with focus on nutritional data will serve as the basis for health care professionals to gather information, and they will use it to make the nutrition diagnosis. This questionnaire consists of 10 questions or statements including one question related to the adequacy of weight 


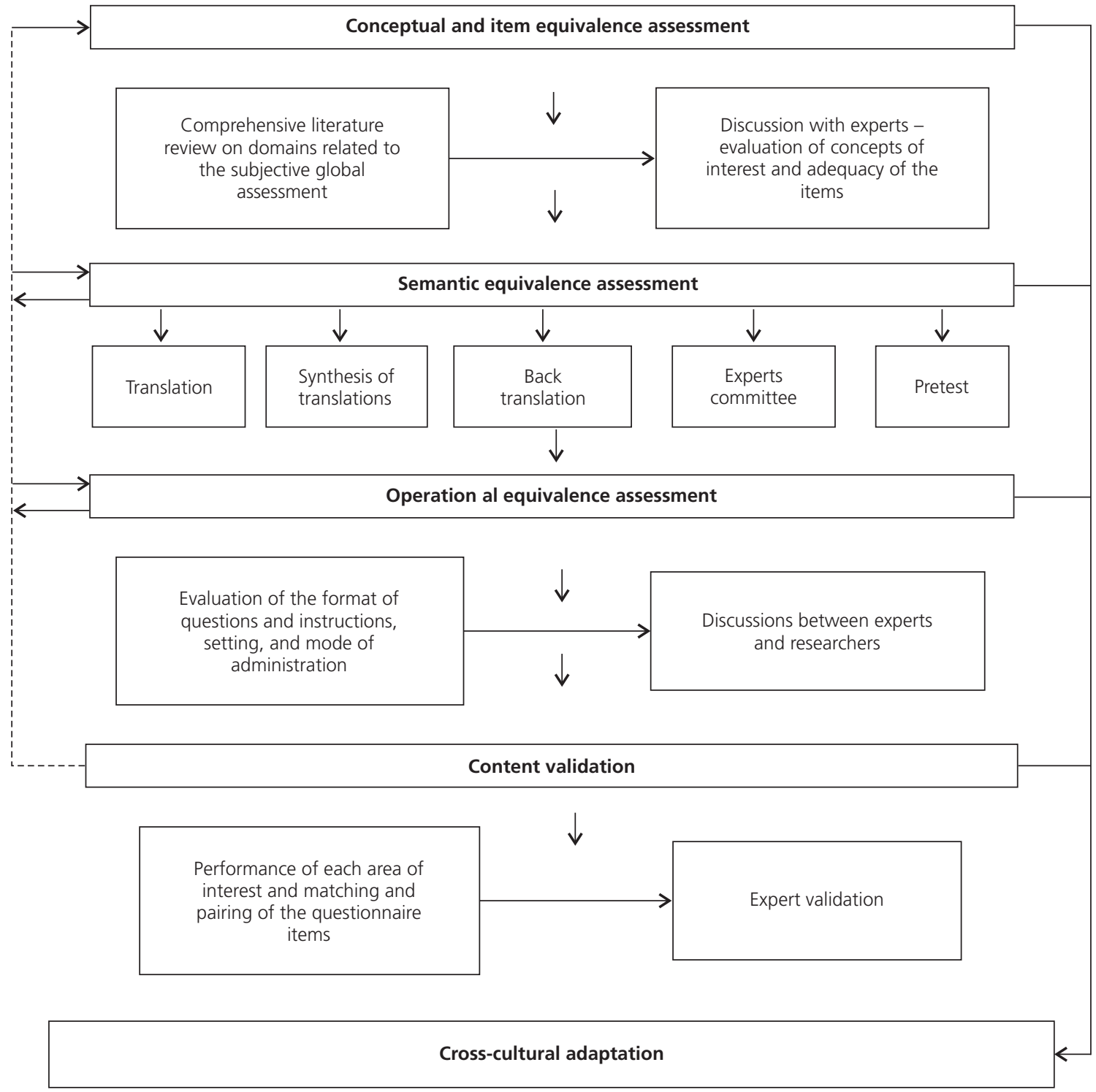

Figure 1. Stages of cross-cultural adaptation of the Subjective Global Nutritional Assessment into Portuguese. Universidade Federal do Rio de Janeiro, Instituto de Nutrição Josué de Castro and Instituto Nacional de Câncer José Alencar Gomes da Silva (Nutrition and Dietetic Service, Cancer Hospital I). Rio de Janeiro (RJ), Brazil (2014).

and height, seven questions about dietary intake, one about gastrointestinal symptoms, and one about functional capacity. Physical examination was performed based on the anatomical regions where there are adipose and muscle tissues since the loss of these tissues indicates the patient is at nutritional risk. The presence of edema was also verified.

It was carried out through extensive review of scientific literature on the concepts that allowed designing the original questionnaire and its applicability in the Brazilian context of pediatric cancer patients. Discussions were then held with 11 health care professionals with expertise in oncology, pediatrics, and nutrition: 2 oncology dietitians, 3 pediatric oncology dietitians, 4 pediatric dieticians, and 2 medical doctors, pediatric hematologists. The experts discussed the concepts of interest and the adequacy of the items that would be relevant 
and pertinent to the new environment that is being adapted.

Semantic equivalence of the instrument was carried out by initial translation, synthesis of the translation, back translation, discussions with the expert committee, and pretest, as described by Saraiva et al. [14]

It is important to mention that each aspect evaluated in the semantic equivalence step depends on specific forms to systematize each assessment, such as the general meaning (connotative) conveyed in the Portuguese version compared to that in the original version in English and the referential in the back translation (denotative meaning) assigned by the experts [15]. The pretest step enabled verifying the applicability of the instrument in a population of pediatric patients with cancer at the Instituto Nacional de Câncer, Rio de Janeiro (RJ), Brazil, between July and August 2014.

It was carried out through evaluation by the researchers and the expert committee of the adequacy of the format of the questions and instructions, setting, and mode of administration.

It concerns to the degree to which an instrument reflects the studied phenomenon. This is not a statistical evaluation, but rather the experts' appraisal regarding the content of the items [13]. It was carried out through the following stages [16]: the performance of each area of interest of the questionnaire was defined; evaluation by an expert committee; a structured script that evaluated the correspondence between the items; and the domain, collection, and summary of the matching process data.

This study was approved by the Research Ethics Committees of the Hospital Universitário Clementino Fraga Filho of the Universidade Federal do Rio de Janeiro and of the Instituto Nacional de Câncer (INCA, National Cancer Institute). The parents or guardians of all participants, including the adolescents (10-17 years), signed a Consent Form.

\section{RE S U L T S}

With regard to the conceptual and item equivalence, the experts agreed that the items and concepts of SGNA are relevant and applicable to the Brazilian context of subjective global assessment. There were discrepancies in three concepts only: the method of evaluation of the weight-for-height adequacy, the concept of meals, and the description of some common foods.

In the original form, the weight-for-height adequacy did not indicate the anthropometric indicator that should be used to better classify this adequacy. A consensus was reached among the experts about the best indicator, which was determined as the body mass index -for-age, according to the World Health Organization Z-score curves [17] because it is an indicator that covers the entire age range of the studied population.

As for the meals, in the original questionnaire, only three main meals are listed: breakfast, lunch, and dinner. The hospital meals were named according to the Brazilian reality as: breakfast, mid-morning snack, lunch, mid-afternoon snack, dinner, and late-evening snack; these are well-established concepts among the study population. Therefore, a change in the concept of these items in the pretest version was proposed.

With regard to the common foods, the item "tubérculos" was included in the "cereais e grãos" food group because they are widely consumed by the population and have high carbohydrate content, which could not be classified due to their absence in the original instrument. Another concept that indicated discrepancy was the consumption of legumes (beans, peas, lentils, and soybeans, for example) as animal protein substitute. In Brazil, for great part of the population, the consumption of legumes complements the main dish in a meal, which is composed of animal protein, except for the vegetarians. The item "leguminosas" was 
included in the pretest version independently to assess their usual intake.

As for the translations of the original questionnaire, the experts disagreed over 2 questions 26 and 50. When asked about their disagreement concerning statement 26, thee experts mentioned that the words in Portuguese with the greatest difficulty in terms of semantic equivalence were: "atrofia", (wasting) "estoques adiposos", (fat stores) "peso" (weight), and "ingestão" (intake). These terms were later replaced with "perda" (loss), "reservas adiposas" (fat reserves), "peso corporal" (body weight), and "ingestão alimentar" (dietary intake). In statement 50, the phrases "Acesse os estoques musculares no movimento da cabeça para as pernas" (Assess muscle stores, moving from the head to legs), "atrofia dos músculos" (wasting of muscle), and "emaciação muscular" (wasting muscle) were the most conflicting terms, and they were replaced with "Observe as reservas musculares no sentido da cabeça para as pernas" (Test muscle tone by massaging from the head to the legs), "depleção dos músculos" (muscle depletion), and "atrofia muscular" (loss of muscle mass) to achieve semantic equivalence.

A total of 32 patients aged between 2 and 17 years (mean=9.1 years), 17 males, participated in the pretest. All patients or their parents or guardians considered the questionnaire easy to answer, and the only challenging question was "Você/seu filho(a) já tentou, alguma vez, por conta própria, alterar o que come e bebe?" (Do you/your child have ever tried by yourself to change what you eat and drink?) After the pretest, this question was the replaced with "Você/seu filho(a) já tentou, por conta própria, modificar a alimentação?" (Have you/your child ever tried to change your diet by yourself?).

During the pretest, some patients reported having some gastrointestinal symptoms that make food intake difficult. These symptoms, however, were not included in the original version of the questionnaire: mucositis, hypersalivation, odynophagia, and dysgeusia. They were then inserted in the final version since they are very common symptoms exhibited by children with cancer. The symptom "dor no estômago" was changed to "dor abdominal" because many patients or guardians reported such pain as abdominal pain.

Physical examination of patients' buttock region was excluded due to the fact that during the pretest there was great difficulty to examine buttock adipose fat because it made patients feel uncomfortable. Chart 1 shows the final questionnaire after completing the cross-cultural adaptation process.

The authors of the original study suggest that the questionnaire should be self-administered. However, in the discussions with the experts, a consensus was reached that the best way to operationalize the questionnaire administration would be conducting a face-to-face interview. An effort was made to maintain the original layout of the questionnaire in the final version in Portuguese.

The experts identified all domains of the instrument based on the content validation. In the form to be completed by the health care professionals, items 1, 2, and 3 refer to the weight and height adequacy, item 4 to dietary intake, item 5 to gastrointestinal symptoms, item 6 to functional capacity, item 7 to metabolic stress, and item 8 to physical examination. In the questionnaire regarding the interview with the patients, item 1 refers to the weight and height adequacy, items $2,3,4,5,6,7$, and 8 refer to dietary intake, item 9 to gastrointestinal symptoms, and item 10 to functional capacity (Chart 1). After the matching step, the experts did not have doubts about the domain of each item.

The average time to complete the SGNA was 30 minutes divided as follows: 15 for the interview, 3 minutes for the physical exam, and 12 minutes for the health care professional (dietitian) to complete the form. In general, the patients, their parents or guardians, and the health care professionals did not have difficulty understanding the questionnaire. 
Chart 1. Final Version of the Subjective Global Nutritional Assessment for use in pediatric cancer patients. Universidade Federal do Rio de Janeiro, Instituto de Nutrição Josué de Castro, and Institute National de Cancer José de Alencar Gomes da Silva (Nutrition and Dietetic Service - Cancer Hospital I). Rio de Janeiro (RJ), Brazil (2014).

SGNA QUESTIONNAIRE - SUBJECTIVE GLOBAL NUTRITIONAL ASSESSMENT FOR PEDIATRIC PATIENTS

Consider the severity and duration of all changes, as well as recent clinical progress when evaluating each item.

\begin{tabular}{|c|c|c|c|}
\hline \multirow{2}{*}{ NUTRITION-FOCUSED MEDICAL HISTORY } & \multicolumn{3}{|c|}{ SGNA score } \\
\hline & Normal & Moderate & Severe \\
\hline \multicolumn{4}{|l|}{$\begin{array}{l}\text { 1- Adequacy of current height-for-age (short stature) } \\
\text { a) Height percentile: } \\
\square \geq 3 \text { rd percentile } \square \text { slightly below the 3rd percentile } \\
\square \text { further below the 3rd percentile }\end{array}$} \\
\hline \multicolumn{4}{|l|}{ b) Is it adequate based on the average height of the parents*?: $\square$ Yes $\square$ No } \\
\hline \multicolumn{4}{|l|}{$\begin{array}{l}\text { c) Growth monitoring: } \\
\square \text { follow along a percentile } \square \text { increase in percentiles } \\
\square \text { decrease in percentiles (gradually or rapidly) }\end{array}$} \\
\hline \multicolumn{4}{|l|}{$\begin{array}{l}\text { 2- Adequacy of current weight-for-height (according to BMI-for-age) } \\
\text { Ideal body weight (50th percentile BMI-for-age) __ } \mathrm{kg} \\
\text { Percentage of ideal body weight __ \% } \\
\square>90 \% \square 75-90 \% \square<75 \%\end{array}$} \\
\hline \multicolumn{4}{|l|}{$\begin{array}{l}\text { 3- Unintentional changes in body weight } \\
\text { a) Weight monitoring: } \\
\square \text { follow along a percentile - curve pattern remained unchanged } \\
\square \text { crossed upward } \geq 1 \text { percentile - upward shift of the curve } \\
\square \text { crossed downward } \geq 1 \text { percentile - downward shift of the curve }\end{array}$} \\
\hline \multicolumn{4}{|l|}{$\begin{array}{l}\text { b) Weight loss: } \\
\square<5 \% \text { of normal weight }-5-10 \% \text { of normal weight } \\
\square>10 \% \text { of normal weight }\end{array}$} \\
\hline \multicolumn{4}{|l|}{$\begin{array}{l}\text { c) Change within the last two weeks: } \\
\square \text { no change } \square \text { increase } \square \text { decrease }\end{array}$} \\
\hline \multicolumn{4}{|l|}{$\begin{array}{l}\text { 4- Adequacy of dietary intake } \\
\text { a) Dietary intake is: } \\
\square \text { adequate } \square \text { inadequate - hypocaloric } \\
\square \text { grossly inadequate - eats very little of everything }\end{array}$} \\
\hline \multicolumn{4}{|l|}{$\begin{array}{l}\text { b) Current dietary intake } x \text { usual dietary intake: } \\
\square \text { no change } \square \text { increase } \square \text { decrease }\end{array}$} \\
\hline \multicolumn{4}{|l|}{$\begin{array}{l}\text { c) Duration of change: } \\
\square<2 \text { weeks } \square \geq 2 \text { weeks }\end{array}$} \\
\hline \multicolumn{4}{|l|}{$\begin{array}{l}\text { 5- Gastrointestinal symptoms } \\
\text { a) } \square \text { no symptoms } \square \text { one or more symptoms; intermittent } \\
\square \text { some or all symptoms; daily }\end{array}$} \\
\hline \multicolumn{4}{|l|}{$\begin{array}{l}\text { b) duration of symptoms: } \\
\square<2 \text { weeks } \square \geq 2 \text { weeks }\end{array}$} \\
\hline \multicolumn{4}{|l|}{$\begin{array}{l}\text { 6- Functional capacity (related to nutritional status) } \\
\text { a) } \square \text { no dysfunction; active patient; able to carry out age-appropriate activities. } \\
\square \text { limited ability to carry out vigorous physical activities but capable of playing and/ } \\
\text { or participating in light school activities or exhibiting sedentary behavior; less } \\
\text { active; tires easily. } \\
\square \text { physical inactivity or inactive child with little participation in recreational activities; } \\
\text { spends most of the day lying down or sitting; no energy; sleeps often. }\end{array}$} \\
\hline $\begin{array}{l}\text { b) Functional capacity within the last } 2 \text { weeks: } \\
\square \text { no change } \square \text { increase } \square \text { decrease }\end{array}$ & & & \\
\hline
\end{tabular}


Chart 1. Final Version of the Subjective Global Nutritional Assessment for use in pediatric cancer patients. Universidade Federal do Rio de Janeiro, Instituto de Nutrição Josué de Castro, and Institute National de Cancer José de Alencar Gomes da Silva (Nutrition and Dietetic Service - Cancer Hospital I). Rio de Janeiro (RJ), Brazil (2014).

\begin{tabular}{|c|c|c|c|}
\hline \multicolumn{4}{|c|}{$\begin{array}{l}\text { SGNA QUESTIONNAIRE - SUBJECTIVE GLOBAL NUTRITIONAL ASSESSMENT FOR PEDIATRIC PATIENTS } \\
\text { Consider the severity and duration of all changes, as well as recent clinical progress when evaluating each item. }\end{array}$} \\
\hline \multirow{2}{*}{ NUTRITION-FOCUSED MEDICAL HISTORY } & \multicolumn{3}{|c|}{ SGNA score } \\
\hline & Normal & Moderate & Severe \\
\hline \multicolumn{4}{|l|}{$\begin{array}{l}\text { 7- Metabolic stress }{ }^{* *} \\
\square \text { no stress } \square \text { moderate stress } \square \text { severe stress }\end{array}$} \\
\hline $\begin{array}{l}\left.{ }^{*} \text { Target height: girls: (father's height }-13\right)+ \text { mother's height/2 } \\
\text { boys: father's height }+ \text { (mother's height }+13 \text { )/2 (mean) } \\
\text { ** Moderate metabolic stress } \\
\square \text { routine surgery (e.g., small bowel resection) } \square \text { laparoscopic sur } \\
\text { gastroenteritis) } \square \text { pressure ulcer } \\
{ }^{*} \text { Severe metabolic stress } \\
\square \text { major surgeries (e.g., stomach, liver, pancreas, lung, open-hear } \\
\text { ( } \leq 50 \mathrm{~cm} \text { remaining) } \square \text { trauma } \square \text { multiple fractures/burns } \square \text { mu } \\
\text { inflammation } \square \text { multiple pressure ulcers } \square \text { chronic illness-acute } \\
\text { infection } \\
\square \text { hyperthyroidism }\end{array}$ & $\begin{array}{l}\text { ery } \square \text { fract } \\
\text { stectomy, } \\
\text { cute panc } \\
\text { alignant o }\end{array}$ & $\begin{array}{l}\text { infection (e. } \\
\text { my) } \square \text { large b } \\
\text { itis } \square \text { severe } \\
\text { ses } \square \text { aids wit }\end{array}$ & $\begin{array}{l}\text { Onchiolitis, } \\
\text { I resections } \\
\text { is } \square \text { severe } \\
\text { portunistic }\end{array}$ \\
\hline \multirow{2}{*}{ 8- Physical Examination } & \multicolumn{3}{|c|}{ SGNA Score } \\
\hline & Normal & Moderate & Severe \\
\hline \multicolumn{4}{|l|}{$\begin{array}{l}\text { Loss of subcutaneous fat } \\
\square \text { no loss in most or all areas } \\
\square \text { loss in some areas but not in all areas } \\
\square \text { severe loss in most or all areas }\end{array}$} \\
\hline \multicolumn{4}{|l|}{$\begin{array}{l}\text { Loss of muscle mass } \\
\square \text { no loss in most or all areas } \\
\square \text { loss in some areas but not in all areas } \\
\square \text { severe loss in most or all areas }\end{array}$} \\
\hline $\begin{array}{l}\text { Malnutrition-related edema } \\
\square \text { no edema } \square \text { moderate } \square \text { severe }\end{array}$ & & & \\
\hline
\end{tabular}

GUIDELINES FOR GLOBAL SCORE

In order to assign a global score, assess all items in relation to each other. Give greater consideration to changes in weight (weight gain) and growth, food intake, and physical signs of loss of fat and muscle mass. Use the other items to support or improve the assessment. Contextualize recent changes according to the normal or according to the usual/orchronic health state of the patient. Was the patient's initial condition normal or nutritionally compromised?

\section{NORMAL/WELL-NOURISHED}

The patient is growing and gaining weight at a normal rate, has an adequate dietary intake, does not exhibit gastrointestinal symptoms, shows little or no physical evidence of loss of muscle mass, and has normal functional capacity. He/she was classified with a 'Normal' status in all or most categories or showed significant improvement and maintenance of adequate nutritional status. The patient can be considered well-nourished despite some decrease in muscle mass, fat reserves, body weight, and food intake. Such classification was based on recent improvements in items that had been previously classified as moderate or inconsistent.

\section{MODERATELY MALNOURISHED}

The patient exhibits clear signs of reduced weight and/or growth and food intake and may or may not show signs of depletion of body fat reserves, decrease in muscle mass, and changes in functional capacity. Although his/her initial nutritional status was adequate, this patient's nutritional status is declining. Most categories were classified as moderate with a potential risk of progression towards severe malnutrition. 
Chart 1. Final Version of the Subjective Global Nutritional Assessment for use in pediatric cancer patients. Universidade Federal do Rio de Janeiro, Instituto de Nutrição Josué de Castro, and Institute National de Cancer José de Alencar Gomes da Silva (Nutrition and Dietetic Service - Cancer Hospital I). Rio de Janeiro (RJ), Brazil (2014).

\section{EVERELY MALNOURISHED}

The patient has progressive malnutrition with a tendency towards getting lower classification in most or all categories. There are obvious physical signs of malnutrition, such as decreased body fat reserves, loss of muscle mass, weight loss $>10 \%$, decreased food intake, several gastrointestinal symptoms and/or acute metabolic stress, and marked change in functional capacity. Most or all categories were classified as severe with none or few signs of improvement.

\section{\begin{tabular}{l|l|c|c}
\hline General Classification of SGNA & Normal & Moderate & Severe \\
\hline
\end{tabular} \\ SGNA QUESTIONNAIRE - CHILDREN/ADOLESCENTS}

1. a) When was the last time you/your child was weighed and measured?

b) Last recorded weight

c) Last recorded height (stature)

d) Mother' height (stature) father's height (stature)

2. a) How many large meals (lunch and dinner) do you/your child usually eat every day?

b) How many snacks, including breakfast, do you/your child usually eat every day?

3. What kind of food do you/your child eat every day? (Please check all that apply)

$\square$ cereals, grains, and tubers (e.g. bread, rice, pasta and pastries, cookies and crackers, potatoes)

$\square$ vegetables and fruits

$\square$ legumes (e.g. beans, chickpeas, lentils, and peas)

$\square$ meat, fish, chicken, and eggs

$\square$ milk and other dairy products (e.g. cheese, yogurt, pudding, and ice cream)

4. a) Please choose the word that best describes your child's appetite:

$\square$ excellent $\square$ good $\square$ fair $\square$ poor

b) Has your/your child's diet changed recently?

$\square$ No $\square$ Yes $\square$ increased?

$\square$ Yes $\square$ increased? $\square$ decreased ___ (days, weeks, months)

5. Do any of the following problems affect your/your child's nutrition? Please check all that apply

Difficulties with chewing, swallowing, choking, and coughing or development of mucositis

Does your child have any eating habit that may bother or annoy others?

"Does not feel like eating"/"Does not feel hungry"

"Feels full after a few bites of food"

Food allergy, food intolerance, or special diets: (specify)

If you checked yes, please answer the following question: If you/your child did not have food allergy or a special diet, would you/your child eat more foods?

Other foods (specify):

6. Please describe your/your child's current food intake dietary habits:

(Food and beverages and amount consumed)

\begin{tabular}{c|c|c}
\hline Breakfast & Lunch & Dinner \\
\hline & & \\
\hline & & \\
\hline & & \\
\hline
\end{tabular}

\begin{tabular}{l|l|l}
\hline Mid-morning snack & Mid-afternoon snack & Late-evening snack \\
\hline & & \\
\hline & & \\
\hline
\end{tabular}

7. Is anyone in your family on a special diet?

$\square$ No

$\square$ Yes $\square$ (explain):

Do you/your child also follow this special diet? $\square$ No $\square$ Yes 
Chart 1. Final Version of the Subjective Global Nutritional Assessment for use in pediatric cancer patients. Universidade Federal do Rio de Janeiro, Instituto de Nutrição Josué de Castro, and Institute National de Cancer José de Alencar Gomes da Silva (Nutrition and Dietetic Service - Cancer Hospital I). Rio de Janeiro (RJ), Brazil (2014).

8. Have you/your child ever tried to change your diet by yourself?

$\square$ No

$\square$ Yes $\square$ In what way?

9. Have you/your child been experiencing any gastrointestinal symptoms that affect what you eat or drink?

$\square$ No $\square$ Yes (please check all that apply)

\begin{tabular}{l|l|l|l|c|c}
\hline \multirow{2}{*}{ Symptoms } & \multicolumn{2}{c}{ Frequency } & \multicolumn{2}{c}{$\begin{array}{c}\text { How long have you/your child } \\
\text { had these symptoms? }\end{array}$} \\
\cline { 2 - 5 } & Rarely/sometimes & Every 2-3 days & Every day & $<2$ weeks & $\geq 2$ weeks \\
\hline Abdominal pain & & & & & \\
\hline Lack or loss of appetite (anorexia) & & & & & \\
\hline Fell that you might vomit (nausea) & & & & & \\
\hline Vomit or reflux & & & & & \\
\hline Diarrhea & & & & & \\
\hline Constipation ( $\downarrow$ frequency, hard dry and stools) & & & & & \\
\hline Mucositis & & & & & \\
\hline Painful swallowing (odynophagia) & & & & & \\
\hline Distortion of the sense of taste (dysgeusia) & & & & \\
\hline Others (specify): & & & & & \\
\hline
\end{tabular}

10. Please check all that apply to your child or adolescent:

a) $\square$ attends school full time

$\square$ attends school part time:

$\square$ reason: he/she gets tired (a) when attending full time

$\square$ other reasons: (explain):

$\square$ does not attend school:

$\square$ reason: he/she gets very tired (a)

$\square$ other reasons: (explain):

b) $\square$ Has plenty of energy to run and play and play sports with friends and/or other children at school

$\square$ Gets tired and cannot keep up with friends and/or other children at school in running and playing

$\square$ Gets tired and feel weak when climbing stairs

$\square$ Can walk inside the house but feels weak and tired when walking long distances

c) $\square$ Regular sleep pattern

$\square$ Sleeps more than usual

$\square$ Needs to spend most of the day lying in bed, on the couch, or sitting in a wheelchair

d) Are your answers to the questions "a", "b", and "c" common habits that you/your child have?

$\square$ Yes

$\square$ No à has this habit become: $\square$ more intense? $\square$ less intense? How long has it been more or less intense? weeks, or months (days,

\section{PHYSICAL EXAMINATION - CHILD/ADOLESCENT}

Physical examination provides support to the evaluation and adds information to that included in the children medical history. Pay special attention to areas where adipose tissue and muscle mass are found to determine whether there have been significant losses.

\section{Subcutaneous fat}

Obvious loss of adipose tissue indicates severe energy deficit. Check for apparent muscular and skeletal contours: the contours of the upper limbs are evident when there is loss of adipose tissue. Is there volume depletion in the cheeks (loss of fat)? Pinch a fold of skin on the biceps and triceps to see whether there is any fatty tissue between your index finger and thumb. Is there any depression between the lower ribs?

\begin{tabular}{l|l|l|l}
\hline Exam area & No loss & Moderate loss & Severe loss \\
\hline Cheek & & & \\
\hline Biceps & & & \\
\hline Triceps & & & \\
\hline Ribs & & & \\
\hline
\end{tabular}


Chart 1. Final Version of the Subjective Global Nutritional Assessment for use in pediatric cancer patients. Universidade Federal do Rio de Janeiro, Instituto de Nutrição Josué de Castro, and Institute National de Cancer José de Alencar Gomes da Silva (Nutrition and Dietetic Service - Cancer Hospital I). Rio de Janeiro (RJ), Brazil (2014).

5 of 5

\begin{tabular}{|c|c|c|c|}
\hline \multicolumn{4}{|c|}{$\begin{array}{l}\text { Test muscle tone by massaging from the head to the legs. Muscle depletion is identified by protruding or prominent bones around } \\
\text { the clavicle, shoulders (loss of deltoid muscle), scapula, and knees, and slimmer thighs (loss of quadriceps muscle) or calf (loss of } \\
\text { gastrocnemius muscle), which indicate decrease in muscle volume and loss of muscle tone. }\end{array}$} \\
\hline Exam area & No loss & Moderate loss & Severe loss \\
\hline \multicolumn{4}{|c|}{ Temporal Bone } \\
\hline \multicolumn{4}{|c|}{ Clavicle (collar bone) } \\
\hline \multicolumn{4}{|l|}{ Shoulder } \\
\hline \multicolumn{4}{|l|}{ Scapula } \\
\hline \multicolumn{4}{|l|}{ Thighs } \\
\hline Calves & & & \\
\hline
\end{tabular}

3. Malnutrition-related edema

The presence of edema at the ankles or over the sacrum may indicate hypoproteinemia. However, coexisting diseases (e.g. kidney disease or congestive heart failure) may also be the reason for this result. The presence of edema should also be considered when assessing changes in weight.

\begin{tabular}{|c|c|c|c|}
\hline Exam area & None & Moderate & Severe \\
\hline Foot and ankle (during walking) & & & \\
\hline $\begin{array}{l}\text { Sacrum (patients with limited ability to carry out activities or those who spend a lot } \\
\text { of time lying down) }\end{array}$ & & & \\
\hline
\end{tabular}

4. Other physical signs observed that are suggestive of malnutrition:

Note: BMI: Body Mass Index.

\section{DISCUSSION}

In this study, a cross-cultural adaptation of SGNA was performed aiming at obtaining an instrument adapted to the context of hospitalized pediatric patients with cancer. The prevalence of malnutrition in pediatric cancer patients is highly variable (6\% to $50 \%)$, and it depends on the tumor type and location and also on the intensity of treatment [18]. Therefore, nutritional risk screening is required to allow implementing an action in a timely manner [19].

With regard to the semantic equivalence, most instrument items showed good general and referential equivalence when comparing the original version of the instrument to the translated and back translated versions, respectively. According to the experts' assessment, all questions or statements showed good agreement between the original source and the target versions, demonstrating that the translation and back translation did not lead to loss of original meaning, as reported in other studies using the same evaluation method $[20,21]$.

Nutritional screening is a process to identify whether an individual is malnourished or at risk of malnutrition and to determine the need for intervention [22]. In Brazil, there are no nutritional screening questionnaires validated for the pediatric population with cancer.

Among the nutritional screening tools available for hospitalized pediatric patients [23-27], the SGNA is the most comprehensive tool for assessing nutritional risk in children and adolescents with cancer. Several autores $[5,11,12,28]$ have highlighted the importance of two or more translation versions made by qualified translators to allow more options of terms to be used in the target version. They 
add that translators should make independent translations of the instrument. In the present study, the two translations and the two back translations were made independently by qualified translators using rigorous methodology.

To our knowledge, this is the first study to perform the cross-cultural adaptation of SGNA for patients with cancer in Brazil. Another study [29] used this tool to assess the nutrition status of critically ill children in the United States, but the cross-cultural adaptation was not carried out. The patients' parents or guardians who did not understand English were excluded from the study. A translated version of SGNA for pediatric patients has been recently published in Brazil [30]. Comparing it with our study, there are some differences in terms of the adaptation of terms, which is probably justified by the different populations used in the two studies; other differences are due to the fact that in the other study only the translation and back-translation of this instrument were made.

An advantage of our study was the assessment by an expert committee composed of selected members with extensive experience in this subject area, allowing all items to be widely discussed and all suggestions to be decided by consensus, which allowed facilitating the understanding in the adapted version. It was also observed that the evaluation of the instrument through the pretest, either by the patients or their parents or guardians or by the health care professionals (dietitians and medical doctors), was of great importance to improve the quality of the cross-cultural adaptation and ensure that the content of the adapted version had a multidisciplinary scope $[11,28]$.

The instrument had to be adapted using a mode of administration different from that of the original source. Instead of using the self-administration mode, it was adapted to be administered using face-to-face interviews because of the level of education and understanding of the population studied. Similarly, another study
[29] that used the SGNA administered it using face-to-face interviews, confirming the need to change its mode of administration.

After considerable discussion with the experts, content validation was successfully achieved. It was possible to demonstrate that the instrument items are included in the universe of interest of the research. As described by Monteiro \& Horta [13], content validation consists in verifying to what extent the items selected to measure a certain construct represent all of the construct's important features, with the appraisal of a panel of experts.

The time required to use this instrument in clinical practice may hinder its use in hospitals that have limited human resources. Despite this difficulty, it is important to emphasize that pediatric cancer patients are at a greater risk for nutritional depletion; thus, a comprehensive tool to assess their nutritional status is necessary.

The cross-cultural adaptation and content validation of the SGNA allowed obtaining its first version in Portuguese. It was adequately adapted to the Brazilian socio-cultural context, easy to understand, and well accepted among health care professionals and the target population. It is important to highlight the need for the use of validated and culturally adapted instruments to ensure the quality of epidemiological and clinical information in studies using the SGNA. To the best of our knowledge, no study has reported meeting the requirements of a desirable system of subjective nutritional assessment in pediatric patients in Brazil. Further validation steps are essential for the screening of nutritional status of cancer patients in pediatric age group.

\section{A C KNOWLEDGEMENTS}

The authors gratefully acknowledge the expert committee and the translators involved in the crosscultural adaptation process of this instrument for their valuable contributions to this paper. 


\section{CONTRIBUTORS}

DCASARAIVA contributed to study conception and design, data analysis and interpretation and elaboration of the article. NB PINHO and WV AFONSO contributed in the analysis and interpretation of the data. WAF PERES and PC PADILHA contributed to study conception and design, and data analysis and interpretation and revision and approval of the final version of the article.

\section{RE FERENCES}

1. Instituto Nacional de Câncer. Câncer na criança e no adolescente no Brasil: dados dos registros de base populacional e de mortalidade. Rio de Janeiro: INCA; 2008.

2. Instituto Nacional de Câncer José Alencar Gomes da Silva. Estimativa 2014: incidência de câncer no Brasil. Rio de Janeiro: INCA; 2014.

3. Ward E, DeSantis C, Robbins A, Kohler B, Jemal A. Childhood and adolescent cancer statistics, 2014. CA Cancer J Clin. 2014;64(2):83-103. https://doi. org/10.3322/caac.21219

4. Mosby TT, Barr RD, Pencharz PB. Nutritional assessment of children with cancer. J Pediatr Oncol Nurs. 2009;26(4):186-97. https://doi.org/10. $1177 / 1043454209340326$

5. Co-Reyes E, Li R, Huh W, Chandra J. Malnutrition and obesity in pediatric oncology patients: Causes, consequences, and interventions. Pediatr Blood Cancer. 2012;59(7):1160-7. https://doi.org/10.10 02/pbc. 24272

6. Brinksma A, Roodbol PF, Sulkers E, Kamps WA, Bont ESJM, Boot AM, et al. Changes in nutritional status in childhood cancer patients: A prospective cohort study. Clin Nutr. 2015;34(1):66-73. https:// doi.org/10.1016/j.clnu.2014.01.013

7. Sala A, Rossi E, Antillon F, Molina AL, Maselli T, Bonilla $\mathrm{M}$, et al. Nutritional status at diagnosis is related to clinical outcomes in children and adolescents with cancer: A perspective from Central America. Eur J Cancer. 2012;48(2):243-52. https://doi.org/10.1016/j.ejca.2011.06.006

8. Joosten KFM, Hulst JM. Prevalence of malnutrition in pediatric hospital patients. Curr Opin Pediatr. 2008;20(5):590-6. https://doi.org/10.1097/MOP.0b0 13 e32830c6ede

9. Secker DJ, Jeejeebhoy KN. Subjective Global Nutritional Assessment for children. Am J Clin Nutr. 2007;85(4):1083-9.
10. Secker DJ, Jeejeebhoy KN. How to perform Subjective Global Nutritional assessment in children. J Acad Nutr Diet. 2012;112(3):424-31.e6. https:// doi.org/10.1016/j.jada.2011.08.039

11. Beaton DE, Bombardier C, Guillemin F, Ferraz $\mathrm{MB}$. Guidelines for the process of cross-cultural adaptation of self-report measures. Spine. 2000;25(24):3186-91.

12. Reichenheim ME, Moraes CL. Operacionalização de adaptação transcultural de instrumentos de aferição usados em epidemiologia. Rev Saúde Pública. 2007;41(4):665-73. https://doi.org/10.15 90/S0034-89102006005000035

13. Monteiro GTR, Hora HRM. Pesquisa em saúde pública: como desenvolver e validar instrumentos de coleta de dados. Curitiba: Appris; 2013.

14. Saraiva DCA, Afonso WV, Pinho NB, Peres WAF, Padilha PC. Equivalência semântica do Questionário Pediatric Subjective Global Nutritional Assessment para triagem nutricional em pacientes pediátricos com câncer. Rev Nutr. 2016;29(2):211-27. https:// doi.org/10.1590/1678-98652016000200006

15. Reichenheim ME, Moraes CL, Hasselmann MH. Equivalência semântica da versão em português do instrumento Abuse Assessment Screen para rastrear a violência contra a mulher grávida. Rev Saúde Pública. 2000;34(6):610-6. https://doi.org/10. 1590/S0034-89102000000600008

16. Crocker L, Algina J. Introduction to classical and modern test theory. Boston: Cengage Learning; 2006.

17. World Health Organization. WHO Child Growth Standards: Methods and development. Geneva: WHO; 2006.

18. Ladas EJ, Sacks N, Meacham L, Henry D, Enriquez L, Lowry $G$, et al. A multidisciplinary review of nutrition considerations in the pediatric oncology population: A perspective from children's oncology group. Nutr Clin Pract. 2005;20(4):377-93. https:// doi.org/10.1177/0115426505020004377

19. Kondrup J. ESPEN Guidelines for Nutrition Screening 2002. Clin Nutr. 2003;22(4):415-21.

20. Aires MT, Werneck GL. Tradução e adaptação cultural para o português do instrumento "The Bowel Disease Questionnaire", utilizado para a avaliação de doenças gastrointestinais funcionais. Arq Gastroenterol. 2006;43(2):138-53. https://doi. org/10.1590/S0004-28032006000200015

21. Luz LL, Santiago LM, Silva JFS, Mattos IE. Primeira etapa da adaptação transcultural do instrumento The Vulnerable Elders Survey (VES-13) para o Português. Cad Saúde Pública. 2013;29(3):621-8. https://doi. org/10.1590/S0102-311X2013000700019 
22. Teitelbaum D, Guenter $P$, Howell WH, Kochevar ME, Roth J, Seidner DL. Definition of terms, style, and conventions used in A.S.P.E.N. guidelines and standards. Nutr Clin Pract. 2005;20(2):281-5. https://doi.org/10.1177/0115426505020002281

23. Sermet-Gaudelus I, Poisson-Salomon AS, Colomb $\mathrm{V}$, Brusset MC, Mosser F, Berrier F, et al. Simple pediatric nutritional risk score to identify children at risk of malnutrition. Am J Clin Nutr. 2000;72(1):64-70.

24. McCarthy $H$, McNulty $H$, Dixon M, Eaton-Evans MJ. Screening for nutrition risk in children: The validation of a new tool. J Hum Nutr Diet. 2008;21(4):395-6. https://doi.org/10.1111/j.1365-2 77X.2008.00881_31.x

25. Gerasimidis K, Keane O, MacLeod I, Flynn DM, Wright CM. A four-stage evaluation of the Paediatric Yorkhill Malnutrition Score in a tertiary paediatric hospital and a district general hospital. Br J Nutr. 2010;104(05):751-6. https://doi.org/10. 1017/S0007114510001121

26. Hulst JM, Zwart H, Hop WC, Joosten KFM. Dutch national survey to test the STRONGkids nutritional risk screening tool in hospitalized children. Clin Nutr. 2010;29(1):106-11. https:// doi.org/10.1016/j.clnu.2009.07.006
27. White $M$, Lawson K, Ramsey R, Dennis N, Hutchinson $Z$, Soh $X Y$, et al. A simple nutrition screening tool for pediatric inpatients. J Parenter Enteral Nutr. 2016;40(3):392-8. https://doi.org/10.11 77/0148607114544321

28. Guillemin F, Bombardier C, Beaton D. Crosscultural adaptation of health-related quality of life measures: Literature review and proposed guidelines. J Clin Epidemiol. 1993;46(12):1417-32. https://doi.org/10.1016/0895-4356(93)90142-N

29. Vermilyea S, Slicker J, El-Chammas K, Sultan M, Dasgupta M, Hoffmann RG, et al. Subjective global nutritional assessment in critically ill children. J Parenter Enteral Nutr. 2013;37(5):659-66. https:// doi.org/10.1177/0148607112452000

30. Carniel MP, Santetti D, Andrade JS, Favero BP, Moschen T, Campos PA, et al. Validation of a subjective global assessment questionnaire for children and adolescents for use in Brazil. J Pediatr. 2015;91(6):596-602. https://doi.org/10.1016/j.jped. 2015.03.005

Received: January 5, 2016

Final version: August 18, 2016

Approved: December 12, 2016 